\title{
EGY ESZKÖZTELEN PEDAGÓGUS II.
}

\section{KÖZÖSSÉGGEL ÉS RACIONALITÁSSAL - A FÉLELMEK ELLENÉBEN}

\section{TRENCSÉNYI LÁSZLÓ}

\author{
az Eötvös Loránd Tudományegyetem Pedagógiai és Pszichológiai Karának docense
} trenyo@index.hu

„Robinéni” - mondták róla szeretettel, ám kissé fölényesen az elöttünk járó osztályok - később jeles közéleti személyiségekként feltünt - tanulói. Nekünk „,Judit néni" volt - így, egyszerüen. A fiúk szemtelenebbje becézte csak a háta mögött, úgyszintén alapvetően a szeretet határain belül, ,Juditmamának”. Ebben az igazságtalan az volt, hogy Székely Róbertné, Judit fiatal asszony volt, amikor osztályfőnökünk lett, bár pedagógus-magatartásában mindig is volt valami anyáskodó, különösen, mert valóságosan fiatal anya volt; gyerekeivel kézen fogva jártunk május elsején a Felvonulás téren, versenyeztünk, hogy a legkisebbet, a csaknem karon ülö Katit melyikünk vehesse a nyakába.

A „becenévváltásnak” van értelmezhető jelentése. Judit - mert az a megtiszteltetés ért, hogy kollégaként így szólíthatom - ebben az időszakban, életperiódusban vált - mondhatni szemünk láttára - „felnőtté”, s e felnőtté válásnak, önfejlődésnek (ahogyan csúf zsargonban mondjuk mostanában) reflexióiról rendre, hivatásához tartozónak gondolt tudatossággal, már-már zavarba ejtően be is számolt. (Hogy a névváltásban egy férfinév, férje $S z$. Róbert helyére került a sajátja? Kérem az olvasót, csakis a fenti dimenzióban értékelje, nem tartozik „Judit néni” pedagógusportréját rajzoló személy tollára, s egy pedagógiai folyóirat olvasóira sem az az egyébként fordulatos, mélyen emberi történet, mely „Robihoz” füzte).

Tartozom még az időbeli és térbeli koordináták meghatározásával. Hatvanas évek eleje s a Radnóti Gimnázium. Ezek fontos adatok. Bizonyára alapvetően ugyanaz a tudatos és önreflektív humánum jellemezte akkor is, amikor néhány évre rá igazgatóhelyettesként pedagógiai vezető lett egy másik, jó hírü fóvárosi gimnáziumban, később kora oktatástechnológiai forradalmának megértőjeként az Iskolatelevizió egyik felelős vezetője, majd e, szívesen végzett feladat szerves folytatójaként a Budai Képző AV-studiójának irányítója.

De beszéljünk most a Radnótiról. (Más összefüggésben írtam én erről a világról az 50 éves Radnóti évkönyvében 2009 elején, amelyet Győri János szerkesztett.)

Judit részese volt annak a döntésnek, mely az akkoriban elhallgatott legendás egykori zsidógimnázium falai közt megszerveződő gimnázium a „Himnusz a béké- 
röl” költőjének nevét vegye fel. A döntésnek akkor (is) volt radikális baloldali ellenzéke (kevesellték a mártíriumot egy iskolanévadás motívumaként, a „konszolidáció" „harcos” éveiben valaki mást, aktívabb politikai szereplőt, úgymond harcosabb höst láttak volna szívesen. Mások meg - mi tagadás (s egyébként szintén lappangó érvrendszerekkel) - a költő származását gondolták iskolanévadásra alkalmatlannak. Judit tudta, hogy mit jelent „névadó hősként” Radnóti Miklós neve. „Tiszta szavam sose kormozza be a barna füsttel égő félelem” - e vágyban, s a „nem félés" vállalásában világos pedagógiai, egyben politikai üzenet volt. Hogy e két jelző közül melyik volt ebben az időben Judit számára fontosabb? Megkockáztatom, hogy a gyermekszeretet, a növendékek tisztelete, vagyis a pedagogikum volt a primer érzelem, a primer vállalás, $\mathrm{s}$ ez látszott igazolódni (a maga idejében a maga sajátos, ma már tudjuk, hogy különösen ellentmondásos módján) a konszolidációnak tekintett korszak paternalizmusában, a jövőképhez, a jövő ígéretének túlhangsúlyozásához tartozó gyermekközpontúságában. Judit ezt a félelemnélküliséget várta a konszolidációtól - volt gyermekkori élménye ama „barna füsttel égő félelemről” ettől kívánta megvédeni tanítványait. Mindezzel együtt „szelídebb” (humánusabb és demokratább) világ és világkép alakult ki, egyébként, nem kis részt az ő jóvoltából a Radnótiban is, mint a közvetlenül megelőző, a kardos-karcos késő ötvenes évekbeli volt.

Tartalmi középpontjában a közösség fogalma állt. Az iskolaethosz és a Radnóti-kultusz hálózatba rendezte az iskola tanulói struktúráit. Még arra is volt okos elgondolás, hogy az új első osztálynak harmadikos ,ikerosztály” jutott. (Miért szépítsem? A megfelelö harmadikos osztály KISZ-alapszervezete vette fel az ifjúsági szervezetbe folyamatosan az ,arra érett” elsősöket, s amikor ők is elérték a „kritikus tömeget”: önálló lábra állhattak. Minden politikai tartalomtól függetlenül iskolaközösség-szervező elvnek pompás megoldás volt.) „Ikerosztályunk” aktivistái közül (a véletlen hozta így?) többen készülttek etnográfusnak, valóban később jellegzetesen sok néprajztudóst adott a hazai szakmának. Nos, ez a néprajzi érdeklődés (mármár „,narodnyikizmus” a maga idejében) bizonyára hozzájárult, hogy az iskola névadója által elsiratott erdélyi festő-barát, Dési Huber István legyen az orosz tagozatos osztályhoz tartozó alapszerv névadója. Dési a szocialista festőcsoport tagja volt, erős avantgárd hitvallással ötvözve, de egyúttal - Radnótit idézve - a „dési templom, és a dési fák" festöje is. Nem véletlenül tódultunk osztályostul Török Erzsi népdalkoncertjeire sem. S még máshoz is vezetett ez a választás, de erről később...

Az osztályközösség meghatározó fogalom volt az osztály életében. Mérce Judit megszólalásaiban és koordináló tevékenységében. Negyvenegyen voltunk az osztályban. Mára sokan - meg kell vallani - „kipörögvén a fősodorból” kevesebb nosztalgiával emlékeznek erre a normára, mint az egykori - ha nem is szükös - aktíva tagjai. De - s ezt is meg kell vallani - az egykori osztálytagok 40 év után ma is, jóformán első szóra mozgósíthatók közös ügyekre, ha sokfelé vetette is őket a történelem, s egyre gyakrabban szomorú, kegyeletes hívások szólítják egybe a hajdan- 
volt osztályt. Ez akkor is tény, a legszebb iskolai identitások mintájának egyike! S ebben Judit kovász-szerepe meghatározó volt.

Az osztályfőnöki órák valóban lényeges etikai beszélgetések, valódi diskurzusok voltak, csiszolódhatott közösségfelfogásunk. Akkor is, ha ez a felfogás - ti. az osztályközösségé - arra is alkalmasabb volt, hogy kisebb csoportokra vagy az osztálytól független társulásokra hamar a klikkesedés bélyegét üsse. Úgy gondolom, s tudom is - hiszen Judit egy-egy találkozón ma is megosztja önmagára vonatkozó reflexióit egykori osztályának tagjaival - ezt már ö is árnyaltabban gondolja. (Fentebb már leírtam: Juditot a ,felnőtté válás” folyamatában figyelhettük meg: mi, kamaszgyerekek. S ő ezt vállalta, tudta, pedagógiai eszközként használta. Mondhatnánk - milyen „okosak” lettünk azóta! - Rogersszel: „Én-jét alkalmazta mint eszközt”, miközben makulátlanul kongruens volt!)

Nem volt egyedül. A Radnótinak ebben a korszakában kristályosodott ki a tantestületnek az a csoportja (Kovács Endre, Gábos Adél - Juditnak nemcsak tanár, hanem hajdani osztálytársa - nevét említsük elsősorban), mely elhatárolódott a szektás bürokráciától, a valóságos társadalmi folyamatok felé fordította a tanítványok figyelmét: élénk rokonszenv követte ennek nyomán a feléledő magyar szociográfiát, „Magyarország újrafelfedezését”, olyannyira, hogy Judit támogatásával egyenesen Csoóri Sándor részvételével mutathattuk be saját szociográfiáinkat, s állt élére maga is falujáró útjainknak, magunkszervezte „osztálykirándulásainknak”. E csoport pedagógiai hitvallásához a másik ember, gyerekember feltétlen tisztelete tartozott. Tudom, hogy Judit „felnőtté válása” állomásaként olyan értelmiségi társaságba járt, ahol a „gyermekbarát iskola" megteremtésén álmodoztak. A meseíró Petrolay Margit - Horváth János-tanítvány! - „szalonja” volt ez, Korein Andor, de Török Sándor maga is megfordult ezeken a beszélgetéseken.

Visszatérve az osztályéletre: más öntevékeny kezdeményezésekre is fogékony volt az osztályfőnök. Shakespeare-est, ha a színmüvésznek készülő B. Miklós kezdeményezte azt, rajzkiállítás több képzőmüvészpályára készülő osztálytárs munkáiból, orosz novellaparódia betanulása, ha az élenjáró oroszosok hozzáláttak. Emlékezetes volt egy nagyszabású kortárs-költői felolvasóest - mellyel aztán „turnézhattunk” lakóhelyére, egy külvárosi „dolgozók iskolájába”. Itt ő másodállásban tanított, de fontosnak tartotta ugyanakkor, hogy mi, a leendö értelmiségiek valóságosan találkozhassunk az eszményített eleven munkásosztállyal.

Kirándulások, iskolaújság, gyermekotthonban vállalt partronázs (önkéntes munka kiváló gyakorlat megannyi pedagógusjelöltnek) mind-mind hozzátartoztak az iskola tradícióihoz igazodó, még is a konkrét kihívásokhoz adaptív módon alkalmazkodó a Judit koordinálta osztályélet mindennapjaihoz.

Székely Judit a szaktanár! Meg ne feledkezzünk erröl. Biológiát, kémiát tanított, kemény, a teleológiát tagadó evolucionizmussal. (Emlékszem, egy forint büntetést fizetett az osztálypénztárba a felelö, ha valamely élölény valamely szervére azt mondta: arra szolgál.) A természettudományos ismereteknek világkép-megala- 
pozó szerepét tartotta fontosnak, a gondolkodásmód megalapozását. Többünk esetében sikerrel. Nemcsak a nagy számban kémiát, biológiát hivatásuknak választók körében. Csaknem ennyien lettünk - nyilván a mintát követve - pedagógusok.

A leírtakból megrajzolható a „hatvanas évek” Judit nénijének neveléselmélete. De talán még fontosabb, mélyebb hatású volt didaktikája! S nem is elsősorban bár nem lebecsülendő - nyitottsága a modern közvetítőeszközök alkalmazása iránt. A tanévtervezés magasiskoláját tanulhattam tőle. Nem csak érdekes, gondolkodtató, diskurzusszervező óráira emlékszem - bár ebből is meglepően sokra, szuggesztív előadó és kérdező volt, remek óravázlatokat írt-rajzolt a táblára. A tanév ivére. Ma is hallom, mondjuk áprilisi szavait: „emlékeztek, amikor egy októberi, decemberi óránkon erről és erről beszéltünk...?” Vagy „erről majd tavasszal tanulunk”. A tanévnek volt dramaturgiája, nem csupán egy-egy órának. Ebben a struktúrában a tanárjelöltek - a Radnóti ebben az időben vált gyakorló iskolává - órái (lettek volt önmagukban bármilyen színvonalúak, megjegyzem általában nem voltak roszszak, sok vezetőtanári elemzés, tervezés állhatott mögöttük), szóval a tanárjelöltek órái ennek a tervezett tanévnek gyöngysorába igazodtak, s ebben az egészben jutottak értelemhez.

1965-ben leérettségiztem. Én is tanári pályára álltam. Judit a 10 éves érettségi találkozón adta kezünkbe - annak idején a továbbtanulási laphoz csatolt - jellemzésünket. (Az igazságnak tartozom: volt olyan osztálytársam, aki ma is úgy tudja, ez a jellemzés „kaszálta el” tehetségének megfelelő továbbtanulás elől - ezt azóta „rendezték” egymás között.) Az én „történetemben” a következő elem vált fontossá: Jóra törekvö (vagy valami ilyesmi) ember...- ez állt egy bekezdés élén. A jellemzést annak idején tantestületi vita emelte határozattá. Judittól tudom, az egyik kolléga felcsattant a szöveg hallatán: - Hát hogy-hogy ember? Hát tanuló...! Judit kitartott álláspontja mellett. A tanulószerep mellett elsődleges mégiscsak emberi mivoltunk. Több, mint jelképes történet. Nem csak az (általam írásaimban oly gyakran kritika tárgyává tett) tradicionális iskola szemléletmódját jelképezi. Székely Róbertné, Judit máig érvényes ,,ars pedagogica”-ját is. 